\title{
The Chilcot Report: some thoughts on international law and legal advice
}

Article

Accepted Version

Green, J. A. and Samuel, S. (2017) The Chilcot Report: some thoughts on international law and legal advice. Journal of Conflict and Security Law, 22 (2). pp. 333-352. ISSN 14677954 doi: https://doi.org/10.1093/jcsl/krw023 Available at https://centaur.reading.ac.uk/66517/

It is advisable to refer to the publisher's version if you intend to cite from the work. See Guidance on citing.

To link to this article DOI: http://dx.doi.org/10.1093/jcsl/krw023

Publisher: Oxford University Press

All outputs in CentAUR are protected by Intellectual Property Rights law, including copyright law. Copyright and IPR is retained by the creators or other copyright holders. Terms and conditions for use of this material are defined in the End User Agreement.

\section{www.reading.ac.uk/centaur}

\section{CentAUR}

Central Archive at the University of Reading

Reading's research outputs online 


\title{
The Chilcot Report
}

\section{Some Thoughts on International Law and Legal Advice}

\author{
James A Green* and Stephen Samuel ${ }^{+}$
}

\begin{abstract}
The Report of the Iraq (Chilcot) Inquiry was finally published, 7 years after the Inquiry's creation, on 6 July 2016. The scope of the Inquiry's work was vast, and this was reflected in the enormous size of its final Report. The publication of the Report thus raises a multitude of questions requiring further analysis. In this short article, we aim to contribute some initial thoughts, immediately following the Report's publication, in just two (interrelated) areas. First, we comment on the role of international law in the Chilcot Inquiry. To what extent was international law considered and how was it presented in the Report? We also ask whether the Report reaches any implicit substantive legal conclusions, despite formally refraining from determinations of law. Secondly, we review the Inquiry's findings concerning international legal advice and legal advisers. In particular, we contribute some thoughts on the Report's treatment of questions relating to the appropriate recipients of legal advice and its transparency, the timeliness of advice, the perception and treatment of law and legal advice by the Government, and the independence and quality of that advice.
\end{abstract}

\footnotetext{
* Professor of Public International Law, University of Reading.

+ Doctoral Candidate, University of Reading. The authors would like to thank April Longstaffe for her research assistance and the ESRC funded 'Commissions of Inquiry: Problems and Prospects' project based at the Human Rights and International Law Unit, University of Liverpool, for the financial support both in relation to financing April's work for us and for funding our trip to Liverpool in January 2015 (well before the publication of the Chilcot Report in July 2016) to present a work-in-progress version of our underpinning research. We also wish to thank the participants at the Liverpool workshop for their feedback, and, in particular, Professor Christian Henderson. All websites accessed 22 July 2016.
} 


\section{Introduction}

The Iraq Inquiry - commonly known as the Chilcot Inquiry, after its chairperson, Sir John Chilcot - was announced on 15 June 2009 by then UK Prime Minister Gordon Brown, ${ }^{1}$ and was formally launched on 30 July $2009 .^{2}$ It was constituted as a non-statutory inquiry, ${ }^{3}$ to independently 'consider the period from summer 2001, before military operations began in March 2003, and [the UK's] subsequent involvement in Iraq right up to the end of July [2009].'4

The Inquiry was an enormous undertaking in many respects. According to its own cost analysis, its total expenditure from 2009 to the publication of its Report was $£ 10,375,000 .^{5}$ Its work spanned 7 years; the publication of its Report was, of course, controversially and repeatedly delayed. ${ }^{6}$ The Chilcot Report was finally published on 6 July $2016^{7}$ It comprised twelve volumes (as well as an executive summary) and, famously, ran to over 2.6 million words. $^{8}$

Given the scope of the Inquiry's work, not to mention the sheer size of its final Report, there exist a vast number of questions that require further analysis post-publication. Our aim

\footnotetext{
1 HC Deb (15 June 2009) Hansard, www.publications.parliament.uk/pa/cm200809/cmhansrd/cm090615/debtext/90615-0004.htm.

${ }^{2}$ Iraq Inquiry Launched (30 July 2009) www.iraqinquiry.org.uk/the-inquiry/news-archive/2009/2009-07-30opening/.

${ }^{3}$ In the UK a clear distinction is drawn between 'statutory' and 'non-statutory' inquiries, with most of the former usually being set up under the Inquiries Act 2005 (c.12). See Select Committee on the Inquiries Act 2005, House of Lords, Report of Session 2013-14, The Inquiries Act 2005: Post-Legislative Scrutiny (The Stationery Office Limited 2014). As a non-statutory inquiry, Chilcot retained a notable degree of independent discretion and procedural flexibility. See Stephen Samuel and James A Green, 'Domestic Commissions of Inquiry and International Law: The Importance of Normative Authority' in Christian Henderson (ed), Commissions of Inquiry: Problems and Prospects (Hart Publishing forthcoming 2017).

${ }^{4}$ Hansard (15 June 2009) (n 1).

${ }^{5}$ Inquiry Costs, www.iraqinquiry.org.uk/the-inquiry/inquiry-costs/ (setting out a full financial breakdown).

${ }^{6}$ See, e.g., Stephanie Boland, 'What Do We Know about the Chilcot Inquiry Report, and When Will it be Published?' New Statesman (16 May 2016) www.newstatesman.com/politics/uk/2016/05/what-do-we-knowabout-chilcot-inquiry-report-and-when-will-it-be-published; and 'Chilcot Iraq Inquiry: MPs to Debate Report Delays’ BBC News (13 January 2015) www.bbc.co.uk/news/uk-politics-30788981.

7 The Report of the Iraq Inquiry (Report of a Committee of Privy Counsellors), 6 July 2016 (Chilcot Inquiry), www.iraqinquiry.org.uk/the-report (comprising twelve volumes and executive summary).

${ }^{8}$ Indeed, it has quickly become a common media trope to point out that the report is 'four times the length of War and Peace'. See Emily Allen, 'Chilcot Inquiry: What is It and What Did the Iraq War Report Say?' The Telegraph (5 July 2016) www.telegraph.co.uk/news/2016/06/28/chilcot-inquiry-when-is-the-report-being-published-andwhy-has-i/.
} 
is extremely modest in comparison to the scale of the Inquiry. In this article, we wish to contribute to one area of discussion, which has already begun in the media and international law blogosphere since the Report was released. ${ }^{9}$ This discussion has two interrelated dimensions. First, we comment on the role of international law in the Chilcot Inquiry and, secondly, we consider the Inquiry's conclusions concerning international legal advice and legal advisers. Our focus in this paper is not on substantive legal issues per se. In particular, we deliberately side-step the question of whether the intervention of Iraq in 2003 was lawful or unlawful. This is partly because that ad bellum question has been significantly, and continuingly, evaluated elsewhere since late-2002. ${ }^{10}$ Furthermore, the Chilcot Inquiry's mandate did not allow for it to reach formal legal determinations, and its Report made it explicit that it did not do so. ${ }^{11}$

While the Inquiry did not make legal conclusions, the topic of international law was significant and manifested itself in various ways during the Inquiry's 7-year odyssey. In particular, the Chilcot Report engaged in detail with the process of legal advice and decisionmaking in relation to the Iraq intervention and its aftermath. Given space constraints and a desire to provide timely commentary (at the time of writing, the Report was released just 16 days ago), our present aim is not to embark on a complete description of the contemporary

\footnotetext{
${ }^{9}$ See, e.g., Elizabeth Wilmshurst, 'We Ignored the Rule of Law - The Result was Iraq' The Guardian (6 July 2016) www.theguardian.com/commentisfree/2016/jul/07/ignored-rule-law-war-result-was-iraq-un-charterforeign-office-lawyer-2003?CMP=fb_gu; Jamie Doward and Chris Ames, 'Whitehall's Secret Advice on Chilcot Will Not be Released' The Observer (9 July 2016) www.theguardian.com/uk-news/2016/jul/09/whitehall-holdsback-official-advice-on-iraq-war; Oona Hathaway, 'What the Chilcot Report Teaches Us About National Security Lawyering' Just Security (11 July 2016) www.justsecurity.org/31946/chilcot-report-teaches-national-securitylawyering/; John Bellinger, 'The Chilcot Inquiry and the Legal Basis for the Iraq War' Lawfare (11 July 2016) www.lawfareblog.com/chilcot-inquiry-and-legal-basis-iraq-war; and Marko Milanovic, 'A Rejoinder to John Bellinger on the Chilcot Report' EJIL:Talk! (13 July 2016) www.ejiltalk.org/a-rejoinder-to-john-bellinger-onthe-chilcot-report/.

${ }^{10}$ See Charlotte Peevers, The Politics of Justifying Force: The Suez Crisis, the Iraq War, and International Law (Oxford University Press 2013) 196 ('the debate [as to the legality of the use of force in Iraq] still rages over ten years after the invasion...'). See, e.g., Dominic McGoldrick, From '9-11' to the Iraq War 2003 (Hart 2004) 4786; Lindsay Moir, Reappraising the Resort to Force: International Law, Jus ad Bellum and the War on Terror (Hart 2010) 73-106; and Marc Weller, Iraq and the Use of Force in International Law (Oxford University Press 2010) particularly $132-88$.

${ }^{11}$ For discussion, see $\mathrm{n} 13-\mathrm{n} 17$ and accompanying text.
} 
procedures of international legal advice and governmental decision-making. ${ }^{12}$ Rather, we simply reflect upon certain aspects of the manner in which the Chilcot Inquiry engaged with and represented international law and legal advice.

\section{The Chilcot Inquiry and International Law}

\section{A. The Role of International Law in the Work of the Inquiry}

At first glance, international law was seemingly excluded as an element of the Chilcot Inquiry's work from the outset. Gordon Brown's announcement of the Inquiry's creation, for example, avoided any reference whatsoever to 'law' or 'legality', in preference of more generic language regarding the 'controversial' nature of the 2003 intervention. ${ }^{13}$ Sir John Chilcot's July 2009 launch statement made it clear that ' $[\mathrm{t}]$ he Inquiry is not a court of law and nobody is on trial. ${ }^{, 14}$ It was thus unsurprising that the 2016 Report stressed in its Introduction that ' $\mathrm{t}$ ]he Inquiry has not expressed a view as to whether or not the UK's participation in the conflict was lawful., ${ }^{15}$

It is not uncommon for the mandates of domestic commissions of inquiry to preclude the commission in question from making formal legal determinations. ${ }^{16}$ The Chilcot Inquiry was primarily concerned with the extent to which one may regard the UK officials concerned as being well-informed to make judgments and decisions, rather than ascertaining which

\footnotetext{
${ }^{12}$ For a short synopsis of legal advice in the UK, see, Stephen Samuel, 'British Influences on the 'Ideals' of International Lawyers' in Robert McCorquodale and Jean-Pierre Gauci (eds), British Influences on International Law, 1915-2015 (Brill Nijhoff 2016). For more expansive studies in this area, see Andraž Zidar and Jean-Pierre Gauci (eds), The Role of Legal Advisers in International Law (Brill Nijhoff forthcoming 2016); and Chanaka Wickremasinghe (ed), The International Lawyer As Practitioner (British Institute of International and Comparative Law 2000).

${ }^{13}$ Hansard (15 June 2009) (n 1) col 27.

${ }^{14}$ Statement by Sir John Chilcot, Chairman of the Iraq Inquiry, at a news conference on Thursday, 30 July 2009 (30 July 2009) www.iraqinquiry.org.uk/the-inquiry/news-archive/2009/2009-07-30-opening/statement-by-sirjohn-chilcot-chairman-of-the-iraq-inquiry-at-a-news-conference-on-thursday-30-july-2009/. See also Karen N Scott and Natalie Baird, 'Preface' (2009) 7 New Zealand Yearbook of International Law ix, ix.

${ }^{15}$ Chilcot Report (n 7) introduction [99-100]. See also Statement by Sir John Chilcot: 6 July 2016 (6 July 2016) www.iraqinquiry.org.uk/media/247010/2016-09-06-sir-john-chilcots-public-statement.pdf, 4.

${ }^{16}$ See Samuel and Green (n 3) section V.
} 
judgment or decision was objectively better. It is notable that none of the Inquiry's members were lawyers (let alone international lawyers). ${ }^{17}$

The decision to restrict the Inquiry's mandate to exclude legal determinations, and particularly - the post-Report refusal to release information regarding the selection criteria that led to it being composed exclusively of non-lawyers, has been subject to revived criticism following the Report's publication. ${ }^{18}$ However, this criticism may, to an extent at least, be unwarranted. This is partly because it is debatable whether it would have been desirable or feasible for the Inquiry to make formal legal pronouncements as to the (ill)legality of the war.

It is tempting for international lawyers to view determinations on substantive international law in commissions of inquiry as being inherently 'positive', especially when the commission in question is dealing with 'fundamental' legal issues (such as human rights or, say, the use of military force), and especially given that such a commission may well be the most formal and 'authoritative' forum in which international law standards could be considered in relation to the given factual circumstances - as was undoubtedly the case for the UK's involvement in the Iraq War. ${ }^{19}$

However, as the present authors have argued elsewhere,${ }^{20}$ it is a mistake to view it as inherently desirable that commissions of inquiry reach substantive international legal determinations. This is because, in many instances, such commissions will not possess the requisite normative authority (given, in particular, the often complex social contexts in which they operate) to be suitable forums for this. ${ }^{21}$ As such, it is questionable whether the Chilcot

\footnotetext{
${ }^{17}$ See Chilcot Report (n 7) introduction [99]. For biographies of the members of the Inquiry, see The Committee, www.iraqinquiry.org.uk/the-inquiry/the-committee/.

${ }^{18}$ See, e.g., Doward and Ames (n 9) (referencing criticism in this regard from Professor Phillipe Sands).

${ }^{19}$ See Chilcot Report (n 7) volume 5, section 5 [579-81].

${ }^{20}$ Samuel and Green (n 3).

21 There are various examples of commissions of inquiry - particularly domestic commissions of inquiry attempting to engage in international legal analysis without possessing the requisite international law expertise: a representative example is the findings of the Malaysian Commission on Immigrants in Sabah (2012-2014) concerning refugee status and on the status of stateless persons, which were wholly unsatisfactory. See Report of the Commission of Enquiry on Immigrants in Sabah, presented to Seri Paduka Baginda Yang di-Pertuan Agong
} 
Inquiry could, or should, have reached substantive legal conclusions, especially given the form in which it was constituted. ${ }^{22}$

The critique of the Inquiry's engagement with international law also somewhat overlooks the fact that, while it was not the Inquiry's role to apply international law, the Report did engage with it. Despite initial appearances, international law was certainly not side-lined: indeed, it was seen as crucial. As Sir John Chilcot stated in a letter to Sir Gus O'Donnell (then Cabinet Secretary) in January 2011, 'the legal basis for military action and the way in which this developed [is] a central part of the Inquiry's work. ${ }^{23}$

It will, of course, be recalled that within a few months of its establishment, the Inquiry had appointed Dame Rosalyn Higgins to advise on matters of international law. ${ }^{24}$ It also went on to solicit submissions from international lawyers in $2010,{ }^{25}$ all 37 of which have now been published on the Inquiry's website. ${ }^{26}$ In its Report, the Inquiry made it clear that Dame Rosalyn's input contributed directly to the Inquiry's procedures and conclusions throughout, ${ }^{27}$ and that the solicited international law submissions 'inform[ed] its consideration of legal issues. $^{28}$

(3 December 2014) www.sapp.org.my/rci/RCI-Eng.pdf, 227-9. For further discussion of this and other similar examples, see Samuel and Green (n 3).

${ }^{22}$ Of course, it is certainly possible for domestic commissions of inquiry to reach credible and informed substantive conclusions of international law. Indeed, the 2010 independent Dutch Committee of Inquiry on the War in Iraq (Davids Committee) did just this in relation to the Iraq War. See, e.g., Rapport Commissie-Davids, Rijksoverheid (Dutch Government) (12 January 2010) www.rijksoverheid.nl/binaries/rijksoverheid/documenten/rapporten/2010/01/12/rapport-commissiedavids/rapport-commissie-irak.pdf, 530-1 [20]. See also Wilmshurst (n 9).

${ }^{23}$ Letter Sir John Chilcot to Sir Gus O’Donnell (6 January 2011) www.iraqinquiry.org.uk/media/96297/2011-0106-Letter-Chilcot-to-ODonnell.pdf.

${ }^{24}$ Military and International Law Advisers Appointed (13 October 2009) www.iraqinquiry.org.uk/theinquiry/news-archive/2009/2009-10-13-advisers-appointed/.

${ }^{25}$ The Iraq Inquiry Invites Submissions from International Lawyers (2 June 2010) www.iraqinquiry.org.uk/theinquiry/news-archive/2010/2010-06-02-submissions-from-international-lawyers/.

${ }^{26}$ International Law Submissions, www.iraqinquiry.org.uk/other-material/submissions-international-law/.

${ }^{27}$ Chilcot Report (n 7) introduction [10].

${ }^{28}$ ibid [98]. 
A perusal of the published communications to and from the Inquiry ${ }^{29}$ indicates that well over 100 of them explicitly, in some measure, refer to questions of international law (and this, of course, does not take into the hundreds of other documents that have been published by the Inquiry). This quantitative inspection is merely indicative, of course: there is a further need to consider the Inquiry's engagement with international law in more qualitative terms.

\section{B. Legal Inferences from the Chilcot Report}

Post-publication, it has been tentatively suggested that, while the Chilcot Inquiry did not explicitly reach legal conclusions, such conclusions could be inferred from its Report, ${ }^{30}$ or, at least, that the Report came 'as close is it [could] to saying that the war was unlawful'. ${ }^{31}$ One could certainly seize the opportunity to extrapolate legal opinions from the Report: its 2.6 million words offer fertile ground for this.

For example, the Inquiry's conclusion that Tony Blair's public statements in January 2003 'were at odds with the draft advice he had received and discussed with Lord Goldsmith'32 is suggestively left hanging, as are various statements made in 2002 by Kofi Annan - the UN Secretary-General at the time - as to the legal need for unequivocal Security Council authorisation for any inter-state use of force. ${ }^{33}$

Elsewhere, the Report strongly gives the impression that the Inquiry shared the consensus position that the right of self-defence could not have provided a legal justification for the use of force. ${ }^{34}$ This view - had it been made as a statement of law - would hardly have

\footnotetext{
${ }^{29}$ This review was conducted on behalf of the authors by April Longstaffe: her research assistance was funded by the ESRC 'Commissions of Inquiry: Problems and Prospects' project. The dataset is on file with the authors.

${ }^{30}$ See, e.g., Caroline Lucas, 'Chilcot Report: Evidence of Deception and Illegality' Caroline Lucas MP, Blog (6 July 2016) www.carolinelucas.com/latest/chilcot-report-evidence-of-deception-and-illegality.

${ }^{31}$ John Rentoul, 'Is Sir John Chilcot Really Saying that Tony Blair Should Have Told the Spies He Didn't Believe Them?' The Independent (6 July 2016) www.independent.co.uk/voices/chilcot-inquiry-report-iraq-war-tonyblair-should-have-told-spies-he-didnt-believe-them-a7122536.html.

${ }^{32}$ Chilcot Report (n 7) volume 5, section 5 [208]. See also ibid [219].

33 ibid, volume 3, section 3.4 [531-3].

34 ibid, volume 5, section 5 [199].
} 
been controversial. After all, even the most advent advocates of intervention within the UK and US governments at the time ultimately decided to steer clear of the self-defence argument in favour of the 'revival' argument. ${ }^{35}$ However, again, the Inquiry was careful not to offer an explicit legal opinion in this regard itself, instead simply noting that there was 'consistent and unambiguous' legal advice pointing in that direction. ${ }^{36}$

The same is true of the Report's consideration of the Government's efforts to comply with International Humanitarian Law in relation to target selection. The Report commended these efforts, but stopped short of confirming that they actually met with success. ${ }^{37}$ Perhaps most starkly, ${ }^{38}$ the Report concluded that

[t]he UK Government was claiming to act on behalf of the international community "to uphold the authority of the Security Council”, knowing that it did not have a majority in the Security Council in support of its actions. In those circumstances, the UK's actions undermined the authority of the Security Council. ${ }^{39}$

Given that the UK's avowed legal basis for the action for the intervention was ultimately Chapter VII authorisation - and, indeed, given that this was the only (even potentially) credible legal basis for that action ${ }^{40}$ - it could be inferred that the Inquiry concluded that the UK's use of force was unlawful, and that this was its diplomatic way of saying so. However, the finding could just as easily be read as indicating that international law was 'complied with' in general, but that this nonetheless undermined the authority of the Security Council.

The present authors are wary of second-guessing unexpressed conclusions on the part of the members of the Inquiry. Ultimately, the Chilcot Report does not make findings of law,

\footnotetext{
${ }^{35}$ See Weller (n 10) 133-44.

${ }^{36}$ Chilcot Report (n 7) volume 5, section 5 [199].

37 ibid, volume 5, section 6.2 [822-5].

${ }^{38}$ See Wilmshurst (n 9).

${ }^{39}$ Chilcot Report (n 7) executive summary [439] (emphasis added).

${ }^{40}$ Although, with regard to dubious alternative legal arguments, see McGoldrick (n 10) 67-78.
} 
as is to be expected given its mandate; inferring such findings is undoubtedly possible, but such an exercise is unhelpfully speculative.

\section{The Chilcot Report's References to International Law}

International law was nevertheless a key element of the Inquiry's Report. The Inquiry's commitment to international legal accuracy and clarity is evident throughout. Irrespective of its refusal to make legal determinations, the Inquiry certainly has not been afraid to set out and highlight international law to a notable extent. ${ }^{41}$ For the most part, in so doing, has achieved a good balance between legal literacy and accessibility.

For example, in relation to questions of target selection, the Chilcot Report helpfully sets out the key rules of International Humanitarian Law (IHL): i.e., distinction, proportionality, military necessity and precaution in attack. ${ }^{42}$ Its summary of these principles is not only legally accurate, ${ }^{43}$ but, moreover, is well filtered and succinctly presented. The Report also provides a similar, albeit more in-depth, summary of the IHL obligations concerning the preservation of religious, historic and cultural property. ${ }^{44}$

With regard to the crucial question of the ad bellum basis for the 2003 intervention, the controversial 'revival argument' is accessibly presented and explained in the Report. ${ }^{45}$ Another indicative example of the Inquiry's approach - in the context of the revival argument - is the fact that key provisions of the 1969 Vienna Convention on the Law of Treaties ${ }^{46}$ relating to

\footnotetext{
${ }^{41}$ It is worth noting that the Chilcot Report did not just touch on substantive questions of international law, but also British domestic law. For example, in sections 15.1 and 15.2, there are a number of reflections upon the common law duty of care owed by various executive departments and bodies to civilian personnel. See, e.g., Chilcot Report (n 7) volume 11, section 15.1 [320-5, 439-44, 833-7]; and section 15.2 [39-59].

${ }^{42}$ Chilcot Report (n 7) volume 5, section 6.2 [349-50]. See also ibid, volume 12, section 17 [53] (similarly credibly summarising the same key IHL principles, but as applicable to civilian casualties).

${ }^{43}$ See generally Ian Henderson, The Contemporary Law of Targeting: Military Objectives, Proportionality and Precautions in Attack under Additional Protocol I (Martinus Nijhoff 2009).

${ }^{44}$ Chilcot Report (n 7) volume 5, section 6.2 [803]. See generally Roger O'Keefe, The Protection of Cultural Property in Armed Conflict (Cambridge University Press 2006).

${ }^{45}$ See, e.g., Chilcot Report (n 7) volume 5, section 5 [534-5].

${ }^{46}$ Vienna Convention on the Law of Treaties 1155 UNTS 331 (23 May 1969).
} 
legal interpretation are reproduced in full. This provides anyone reading the Report, who may not have a background in international law, with a valuable tool with which to undertake assessment of the Security Council resolutions that formed the basis of the UK's legal case. ${ }^{47}$

This is not to say that the Inquiry's engagement with international law was unfailing. For example, its offhand summary of the jus ad bellum as the "prohibition on the use of force except in self-defence or where clearly authorised by the Security Council', ${ }^{48}$ while broadly accurate, is devoid of nuance and paints a picture that might act to somewhat obscure the complex realities concerning the law on the use of force. Such representations perhaps further underscore the view that it would not have been appropriate or desirable for Chilcot to have had a mandate to reach concrete legal findings. ${ }^{49}$

Nonetheless, for the most part, the way in which the Inquiry has engaged with international law - both in terms of depth and accuracy - is pleasing. Significant international legal discourse in the UK regarding the Iraq War has run parallel to the Inquiry's work, and has been fuelled by it. As Peevers has argued, "the Inquiry itself generated a "resurgent" debate over Iraq War decision-making and, during the hearings, we perhaps heard more than ever before about the legal aspects of the decision to go to war. ${ }^{50}$ The Inquiry's high profile means that the admirable care taken in its Report's representations of international law has the potential to improve future engagement with international law by British commissions of inquiry, as well contributing positively to the wider social awareness of international legal standards in the UK.

\section{The Chilcot Inquiry and International Legal Advice}

\footnotetext{
${ }^{47}$ Chilcot Report (n 7) volume 5, section 5 [108].

48 ibid, volume 5, section 5 [574].

${ }^{49}$ See n $19-$ n 22 and accompanying text.

${ }^{50}$ Peevers (n 10) 55.
} 
It has already been noted that the Chilcot Inquiry was not a body capable of making legal determinations and never framed itself in these terms. ${ }^{51}$ Perhaps as a result, the Inquiry perceived one of its roles as not merely being to analyse the 'content' of the legal advice given to government in relation to the Iraq War, but also to engage with the means and occasions by which advice was provided and received. The legal advice that formed the basis of the justification for war is a central element of Chilcot: most notably, section 5 of the Report running to 169 pages and over 70,000 words - is devoted entirely to the question of the advice that formed the basis for the UK's legal case for the intervention, ${ }^{52}$ although it is important to note that questions concerning legal advice (its nature, delivery and reception) are explored throughout the Report. ${ }^{53}$

Writing in 2009, not long after the Chilcot Inquiry's creation, Scott and Baird argued that it was already the case that the Inquiry had 'led to unprecedented scrutiny of the role of the government legal advisor. ${ }^{54}$ Such scrutiny has continued throughout the 7 years of the Inquiry's existence. ${ }^{55}$ The Chilcot Inquiry has thus, arguably unintentionally, somewhat 'democratized' the nature of the provision of legal advice to governments, ${ }^{56}$ by bringing public attention to certain features of international legal expertise and advice. The events of the Iraq War, with which the Inquiry was concerned, did not merely engage substantive legal questions, they also raised existential questions about international law generally. ${ }^{57}$ Many of the features

\footnotetext{
${ }^{51}$ See n 13 - n 17 and accompanying text.

${ }^{52}$ Chilcot Report (n 7) volume 5, section 5.

${ }^{53}$ See, e.g., ibid, volume 2, section 3.3 [90, 485-502]; volume 5, section 6.1 [301]; volume 5, section 6.2 [351-75, 713-800]; volume 9, section 10.1 [154-7]; and volume 10, section 11.1 [55].

${ }^{54}$ Scott and Baird (n 14) ix.

55 See Peevers (n 10) 55.

${ }^{56}$ Were it not for the creation of the Chilcot Inquiry, which led to the declassification of many government documents, it would have likely taken decades for the matter to be truly exposed to public scrutiny, given that the 1967 amendment of the Public Records Act 1958 (c.51) imposes a 30-year-rule for declassification.

57 See, e.g., Tom Blass, 'The Iraq Inquiry' International Bar Association (6 January 2011) www.ibanet.org/Article/Detail.aspx?ArticleUid=6c486ccb-6222-428d-88d7-3e2dcbc5c113 (quoting Anne Ramberg, Secretary General of the Swedish Bar Association and Co-Chair of the IBA's Rule Of Law Action Group).
} 
of international legal advice and existential questions about international law that fell within the Inquiry's mandate have long been recognised within professional circles,${ }^{58}$ but the Chilcot Report has uniquely highlighted them and made them a matter of public record.

The role of the legal adviser, as the name suggests, is to advise. This, though, begs a number of questions, both generally and in relation to the UK's role in the Iraq War. For the purposes of this article, we briefly touch upon just a few such questions, as manifested in the Report: the appropriate recipient of legal advice and its transparency, the timeliness of advice, the perception and treatment of law and legal advice by the Government, and the independence and quality of that advice. These particular points are complex and wide-ranging. As such, for sake of brevity, our discussion of them is necessarily selective. It is, however, worth keeping in mind that underpinning the discussions in this section is Chilcot's ultimate conclusion that 'the circumstances in which it was decided that there was a legal basis for UK military action were far from satisfactory. ${ }^{59}$

\section{A. The Recipients and Transparency of Legal Advice}

The Chilcot Report highlights the difficulty in determining to whom the legal adviser owes a responsibility to provide advice. Differing perspectives in this regard became notably apparent in the course of the Inquiry's work. Lord Goldsmith, for example, 'told the Inquiry that he viewed Mr Blair as "ultimately" the client for his advice. ${ }^{60}$ In direct contrast, the Cabinet Secretary, Lord Turnbull, was of the view that 'he, Admiral Sir Michael Boyce, Chief of the

\footnotetext{
${ }^{58}$ The features of, and the many difficulties faced by, government legal advisers are a frequent theme in the literature. See, e.g., 'Symposium, Speaking Law to Power: International Law and Foreign Policy' (2005) 23 Wisconsin International Law Journal 1; Zidar and Gauci (eds) (n 12); and Wickremasinghe (ed) (n 12).

${ }^{59}$ Statement by Sir John Chilcot (6 July 2016) (n 15) 4 (emphasis added).

${ }^{60}$ Chilcot Report (n 7) volume 5, section 5 [159].
} 
Defence Staff (CDS), the diplomatic service and others were all clients for Lord Goldsmith's advice. $^{, 61}$

Chilcot confirms that the acquisition of formal advice in relation to the legality of the use of force was deliberately delayed, ${ }^{62}$ and that early informal legal advice was kept within an extremely tight circle of only a few people. ${ }^{63}$ It is also the case that, once it was finally obtained, formal legal advice was not presented to Cabinet in a timely manner. ${ }^{64}$ The Chilcot Report is clear that Mr Blair and Mr Straw in particular acted as conduits between the legal advisers and the Cabinet (and other senior officials) in this regard, filtering and controlling the flow and quality of information. ${ }^{65}$

The Inquiry accepted that, constitutionally, there was no requirement for legal advice to be presented to Parliament, ${ }^{66}$ despite its conventional - if not legal ${ }^{67}$ - role in decisionmaking concerning the use of force (a role that has strengthened notably since the 2003 intervention). ${ }^{68}$ The Inquiry also agreed ${ }^{69}$ with the Mr Blair's contention ${ }^{70}$ that government was entitled to confidential legal advice. What the Inquiry took exception to, however, was the fact that advice was not communicated to the wider Cabinet and other key officials: it was unequivocal in holding that ' $\mathrm{t}$ ] he advice [prepared by the Attorney General] should have been provided to Ministers and senior officials whose responsibilities were directly engaged and should have been made available to Cabinet. ${ }^{, 71} \mathrm{Mr}$ Blair and Mr Straw's restrictive approach

\footnotetext{
61 ibid [163] (emphasis added).

${ }^{62}$ See subsection 3.B.

${ }^{63}$ Chilcot Report (n 7) volume 5, section 5 [454-6, 908 and 914].

64 ibid [825-85].

${ }^{65}$ See, e.g., ibid [908].

66 ibid 5 [679] (citing Thomas Erskine May, Parliamentary Practice (22nd edn, Butterworths 2001)).

${ }^{67}$ Chilcot Report (n 7) volume 5, section 5 [22].

${ }^{68}$ The Cabinet Manual: A Guide to Laws, Conventions and Rules on the Operation of Government (Cabinet Office 2011) [5.36-5.38]; and Constitutional Arrangements for the Use of Armed Force - Constitution Committee, $\begin{array}{llllll}\text { Chapter } & \text { 2: } & \text { Chapter } & \text { Parliament's } & \text { Role } & \text { (2003) }\end{array}$ www.publications.parliament.uk/pa/ld201314/ldselect/ldconst/46/4606.htm\#a11.

${ }^{69}$ Chilcot Report (n 7) introduction [73].

70 ibid, volume 5, section 5 [808].

71 ibid [957].
} 
to disseminating legal advice was thus deemed unsatisfactory by the Inquiry: '[a]s the Attorney General, Lord Goldsmith was the Government's Legal Adviser not just the Legal Adviser to Mr Blair. ${ }^{72}$

Chilcot's position in this regard must be correct, given that the Cabinet is the ultimate decision-making body in the Government regarding the use of force. ${ }^{73}$ In relation to the Iraq War specifically, the restrictive approach to the access to legal advice undoubtedly undermined the relationship between the Government and its legal advisers. More generally, this has wider implications for the place of international law in governmental decision-making and the domestic democratic rule of law.

\section{B. The Timeliness of Legal Advice}

It is evident from the Report that there was a notable delay in the Government's seeking of formal legal advice, particularly from the Attorney General. ${ }^{74}$ Indeed, it was not simply the case that advice was not sought: despite the willingness of the Attorney General ${ }^{75}$ (and other legal advisers ${ }^{76}$ ) to provide it, Lord Goldsmith was instructed not offer a legal response until called upon. ${ }^{77}$ This highlights not only an omission, but also a deliberate choice to block early legal analysis of the plans to use military force (plans that Chilcot confirm were firmly in place before the end of 2002). ${ }^{78}$

The Report certainly implies that the decision to delay advice was undesirable, ${ }^{79}$ although it stops short of explicitly condemning it. This was, perhaps, because Chilcot had in

\footnotetext{
72 ibid [233].

73 Constitutional Arrangements for the Use of Armed Force - Constitution Committee, Chapter 2: The Government's Internal Decision-Making Process

www.publications.parliament.uk/pa/ld201314/ldselect/ldconst/46/4605.htm [23-5].

${ }^{74}$ See, e.g., Chilcot Report (n 7) executive summary [441]; and volume 5, section 5 [38, 63 and 99].

75 ibid [16 and 119].

${ }^{76}$ See, e.g., ibid [127].

77 ibid [906].

${ }^{78}$ See, e.g., ibid, executive summary [66-9 and 94].

${ }^{79}$ See, e.g., ibid [441-57].
} 
mind the fact that a governmental request for the provision of formal legal advice may have had wider political and strategic implications in the lead-up to war, ${ }^{80}$ particularly when it was relatively clear that the advice in 2002 would have been that the use of force would be unlawful. $^{81}$ This restriction - in effect a gag order on legal advice - placed the legal advisers in an extremely difficult position. ${ }^{82}$ The FCO legal advisers, for example, were clearly perturbed by this obfuscation of legal questions during the initial planning stages of the intervention. $^{83}$ Whereas, the Attorney General was, perhaps unsurprisingly, rather more willing to accept the instruction to refrain from providing formal advice in late 2002, and was prosaic when discussing it in retrospect. ${ }^{84}$

In any event, the deliberate delaying of legal advice (both per se and, then, its communication to the Cabinet and other senior officials as discussed in the previous subsection) further indicates the worrying marginalisation of legal questions by government officials at the time.

\section{The Perception and Treatment of Legal Advice}

There is a recurring perception amongst international lawyers that, as advisers, their role is a 'marginal' one: some practitioners have even described their professional role as that of 'handmaidens' of wider socio-political forces. ${ }^{85}$ The Chilcot Inquiry's account of the events leading up to the 2003 Iraq intervention reflects this perspective to some degree.

\footnotetext{
${ }^{80}$ ibid, volume 5, section 5 [139 and 329].

${ }^{81}$ See, e.g., ibid [166-96].

${ }^{82}$ See, e.g., ibid [132-3].

${ }^{83}$ See, e.g., ibid [127, 133-4 and 139].

84 ibid [16, 38 and 909].

${ }^{85}$ Philip Alston, 'The Myopia of the Handmaidens: International Lawyers and Globalization' (1997) 3 European Journal of International Law 435; and Martti Koskenniemi, 'The Fate of International Law: Between Technique and Politics' (2007) 70 Modern Law Review 1.
} 
At the same time, it is important not to overstate the extent to which legal advice was marginalised in relation to the Iraq War. Chilcot shows us the inner workings of the provision of legal advice to the UK Government in unprecedented depth. ${ }^{86}$ It indicates that there exists a high degree of procedural fidelity to the role of such advice, and that notable significance is placed upon it. ${ }^{87}$ This is not merely because of the need to ensure that any particular action is taken within the law and is immune from disruptive and destabilising legal disputes, but also because supportive legal opinion has the capacity to legitimate decisions and behaviour. ${ }^{88}$ It is important to note that, while Chilcot undoubtedly confirms the marginalisation of legal advice, it also - at the same time - shows that legal advisers are an integral element of British governmental decision-making, and that this was to an extent true even in relation to the events assessed by the Inquiry.

Of course, Chilcot also highlights, in parallel, a rather uglier, more instrumental view of 'the law'. It is clear that at least some senior figures in the Government viewed compliance with international law in relation to Iraq purely as valuable political and procedural 'cover', rather than having any inherent value in itself. ${ }^{89}$ Indeed, such instrumentalisation occurred not only in relation to legal advice, but also with respect to the advisers. One might note, for example, the decision to have Lord Goldsmith present the final legal case for war to

\footnotetext{
${ }^{86}$ See Charlotte Peevers, 'Guest Post Part I: The Chilcot Inquiry - The Publication Saga of an Official History' Opinio Juris (17 February 2015) http://opiniojuris.org/2015/02/17/guest-post-chilcot-inquiry-part-publicationsaga-official-history/.

${ }^{87}$ See, e.g., Chilcot Report (n 7) volume 2, section 3.3 [485-502] (the Inquiry's apparent implicit acceptance of Tony Blair's claim that the Attorney General's advice in July 2002 - to the effect a further SC resolution was undoubtedly required before any intervention could possibly be lawful - was welcome and had a distinct effect on policy, shaping the attempt to obtain what ultimately became resolution 1441); and volume 5, section 5 [140] (Mr Blair's claim that, had advice from the Attorney General unequivocally been that the use of force was unlawful, then the UK 'would have been unable to take action').

${ }^{88}$ This explains why international lawyers have long been keen on formal separation between law and politics, with some even suggesting a more constitutionalist perspective. See Mattias Kumm, 'The Legitimacy of International Law: A Constitutionalist Framework of Analysis' (2004) 15 European Journal of International Law 907.

${ }^{89}$ See, e.g., Chilcot Report (n 7) volume 1, section 2 [164]; volume 2, section 3.4 [34-6].
} 
Parliament. ${ }^{90}$ The Inquiry found this to be an 'unusual' practice, ${ }^{91}$ and stated that responsibility for making the legal case to Parliament should have rested with 'the Minister responsible for the policy, in this case Mr Blair or Mr Straw. ${ }^{92}$ Chilcot stopped short of saying that this 'unusual' approach was motivated by a desire to stave off awkward legal questions in Parliament by presenting a legal fait accompli - an 'authoritative' expert view that would be difficult for MPs to dispute. However, the present authors are more willing to speculate in that regard.

The integral nature of the legal adviser to the process of governmental decision-making means that the expectations placed on the legal advice given tend to be high. ${ }^{93}$ Moreover, 'integral' does not necessarily mean 'integrated' in this context. It is evident from the Chilcot Report that there was little appetite in the Cabinet to engage with legal analysis. ${ }^{94}$ The prevailing view was that the advice should be in a black and white form - war was lawful or unlawful - and any further legal advice was extraneous. ${ }^{95}$ As a result, legal nuance was lost. ${ }^{96}$ From the perspective of the present authors, as international law academics, this is a damning finding. However, it is perhaps reflective of the reality of the role of the government legal adviser. $^{97}$

What is more concerning - and is a key issue apparent from Chilcot in relation to the marginalisation of advice - is that the Inquiry reveals the extent to which legal advice was disputed or rejected by those being advised. The picture painted by the Report is one of outright

\footnotetext{
90 ibid, volume 5, section 5 [943].

91 ibid [943].

92 ibid [944].

${ }^{93}$ See, e.g., ibid [394].

94 ibid [952].

${ }^{95}$ See, e.g., ibid [85, 686, 701, 857-63, 872, 878 and 950].

96 ibid [35].

${ }^{97}$ See, e.g., Sir Franklin Berman, 'The Role of the International Lawyer in the Making of Foreign Policy' in Chanaka Wickremasinghe (ed), The International Lawyer As Practitioner (British Institute of International and Comparative Law 2000) ('It would be a rare case indeed if a Governmental legal adviser were in a position to compel the Government he [or she] serves to act in one way or another... when it comes to action the final decision may not be his [or hers]').
} 
hostility, at least in some quarters, towards legal advice that did not clearly support the policy goals of the Government.

International law was seen by some senior officials - both before and after the March 2003 intervention - as merely a constraining annoyance. ${ }^{98}$ As such, legal advice was at times viewed as being about working around the law's unhelpful restrictions, and, thus, legal advice that was seen as adding to the restrictive nature of the law in any way was dismissed. This perspective is illustrated by Sir John Sawers' statement in February 2002 that ' $[\mathrm{t}]$ he lawyers and peaceniks should not prevent us from saying what we really want in Iraq [i.e., regime change]. ${ }^{99}$

Another stark example from the period immediately prior to the intervention is Jack Straw's rejection ${ }^{100}$ of Sir Michael Wood's warning that a second Security Council resolution was required for force to be lawful. ${ }^{101} \mathrm{Mr}$ Straw wrote to Sir Michael stating: 'I note your advice, but I do not accept it. ${ }^{, 102}$ The Foreign Secretary instead drew upon legal advice from elsewhere, including from US government lawyers, ${ }^{103}$ to reach an alternative legal conclusion. Similarly, one might note that the Prime Minister's Chief of Staff proposed that Sir Jeremy Greenstock be asked to seek alternative (i.e., more agreeable) legal advice to that initially given by Lord Goldsmith. ${ }^{104}$

These rejections of 'undesirable' advice highlight a constitutional tension regarding the role of the legal adviser. The Inquiry noted, for example, Sir Franklin Berman's view that Ministers should not be entitled to cherry pick legal advice to support their preferred policy

\footnotetext{
${ }^{98}$ See, e.g., Chilcot Report (n 7) volume 5, section 6.1 [418].

${ }^{99}$ ibid volume 1, section 3.2, [11-2 and 106-7].

100 ibid, volume 5 , section 5 [349-54].

101 ibid [344-8]. Indeed, Sir Michael went so far as to state that ' $[t]$ o use force without Security Council authority would amount to the crime of aggression.' ibid [348].

102 ibid [351].

103 See, e.g., ibid [358].

104 ibid [197].
} 
option. ${ }^{105}$ However, the Report did not necessarily endorse this view: it merely juxtaposed it with Mr Straw's contrary assertion that advice was - as it were - advisory, ${ }^{106}$ and left the reader to draw their own conclusions on this point.

The current authors take the position that it must be correct that the views of legal advisers cannot replace government policy, as this would in effect turn them into unelected policy-makers. Mr Blair and Mr Straw (amongst others in the Government) surely possessed significant discretionary 'power' to treat the legal advice that they had received as they felt appropriate. ${ }^{107}$ The more important question is the manner in which, and the desirability of the manner in which, they exercised this power. On this front, the Chilcot Report is devastatingly critical. The fact that key figures in the Government failed to adequately explain - except in terms of their beliefs as to what they thought was right ${ }^{108}$ - their reasons for rejecting, delaying and marginalising formal legal advice (and the fact that Chilcot was able to demonstrate this) is telling. The Inquiry, and the wider social and political legacy of a war that most viewed as unlawful, profoundly demonstrate the need to respect the opinions of legal advisers and to adequately justify any departure from those opinions.

\section{The Quality and Independence of Legal Advice}

This article does not aim to consider the content of the advice provided in relation to the Iraq intervention in substantive terms. Certainly, the advice that the Attorney General ultimately provided can and should be questioned, given its departure from the majority opinion amongst other Legal Officers and the wider international legal community. However, in this subsection,

\footnotetext{
105 ibid [382].

106 ibid [358].

107 This is particularly the case when the authorisation of military action is concerned, as this undoubtedly remains one of the prerogative powers of the crown. See Nigel D White, Democracy Goes to War: British Military Deployments Under International Law (Oxford University Press 2009) 19-22. See also n 73 and accompanying text.

${ }^{108}$ See, e.g., Chilcot Report (n 7) executive summary [537].
} 
we are instead concerned with issues affecting the quality and independence of legal advice, ${ }^{109}$ particularly with respect to the advice provided by Lord Goldsmith.

The Attorney General is, of course, the most senior legal adviser to the British Government, and his advice is, therefore, in constitutional terms, paramount. ${ }^{110}$ However, while Lord Goldsmith is an eminent lawyer, he does not have specialised expertise in relation to public international law (and, particularly, in respect to the jus ad bellum). Given this, it is notable that he formulated his legal opinion on ad bellum issues with input from other Legal Officers (notably FCO legal advisers and the UKMIS legal team in New York). ${ }^{111}$ Such consultation and pooling of legal opinion is surely highly desirable, both in terms of broadening legal appraisal and engaging subject-specific expertise. However, the Chilcot Report noted Sir Michael Wood's view that:

the Foreign Secretary was content for me to send the letter provided I did not include in the letter a statement of my own view of the law; and provided that I made it clear in the letter that no advice was needed at present. I was not happy with these instructions... ${ }^{112}$

The suggestion by Mr Straw that FCO legal advisers should not take a position on the law when instructing the Attorney General was certainly problematic. In effect, due to the Foreign Secretary impairing communication between legal advisers, the Report also noted that a divergence of views amongst Legal Officers 'crystallised when it became clear that a second resolution would not be forthcoming.' ${ }^{113}$ Clearly it would have been desirable for full and

\footnotetext{
109 This matter has, quite rightly, already been engaged within the blogosphere. See, e.g., Richard Moorhead, 'Independence Play - Chilcot on the Legal Process' Lawyer Watch (7 July 2016) www.lawyerwatch.wordpress.com/2016/07/07/independence-play-chilcot-on-the-legal-process/.

${ }^{110}$ See Chilcot Report, volume 5, section 5 [852].

${ }^{111}$ See ibid [109-128], volume 2, section 3.5 [1004].

112 ibid, volume 5, section 5 [127].

113 ibid, volume 2, section 3.5 [1064].
} 
frank communications in this regard to have occurred, and this should have been encouraged by government rather than restricted.

It has long been apparent that in the early months of 2003 there were significant changes, 'in both tone and content' ${ }^{114}$ to the legal advice provided by the Attorney General. ${ }^{115}$ However, the Chilcot Report painstakingly charts the progression of Lord Goldsmith's legal analysis, exposing it to a huge amount of scrutiny.

Lord Goldsmith's preliminary view was he was 'not optimistic'116 and even 'pessimistic' ${ }^{\prime 17}$ about the legal position for military action without a second Security Council resolution, and he was clear that a further decision of the Security Council at least was required. ${ }^{118}$ There was then something of a shift, to a position that identified two competing legal arguments. One of these, of course, was that a 'reasonable case' could be made for authorisation by way of resolution 1441 alone, ${ }^{119}$ albeit that the Attorney General felt that a second resolution was still 'the safest legal course' ${ }^{120}$ and that there was no guarantee that a court of law - were it ever to consider the question - would find in favour of this position. ${ }^{121}$ The final version of the Attorney General's formal legal advice, famously, was that the 'better view' was that there was a legal basis for the use of force without a further Security Council resolution. ${ }^{122}$ As is well-known, this third and final legal position - which best aligned to the Government's pre-determined policy course - 'was the basis on which military action was taken. $^{123}$

\footnotetext{
${ }^{114}$ Duncan French, 'Iraq and Climate Change: The Mainstream Lawyer's Survival Guide' (2010) 44 International Lawyer 1019, 1025.

${ }^{115}$ See, e.g., Andrew Gilligan, 'Why Did the Attorney General Change His Advice?' The Spectator (6 March 2004) www.spectator.co.uk/2004/03/why-did-the-attorney-general-change-his-advice/.

${ }^{116}$ Chilcot Report (n 7) volume 5, section 5 [5].

117 ibid [20].

118 ibid [176, 184 and 289].

${ }^{119}$ See, e.g., ibid [916 and 922].

120 ibid [460].

121 ibid [557 and 579].

122 ibid [933].

${ }^{123}$ ibid [687].
} 
The Chilcot Report does not shy away from confirming that there was 'a change of view' on the part of the Attorney General. ${ }^{124}$ It is not explicit as why this change occurred, although it does provide indicative evidence in this regard. Lord Goldsmith's view was, for example, influenced by 'the arguments of the US Administration which [he] heard in Washington', ${ }^{125}$ and by 'discussions with Mr Straw, Sir Jeremy Greenstock and the US Administration'.126

There was a degree of sustained political pressure placed on the Attorney General internally. In general, this was subtle and indirect, rather than overt. For example, the question posed to the legal advisers became framed in terms of whether a legal case could or could not be made, rather than as a request for opinion as to what the strongest legal position was. ${ }^{127}$ When the question being asked is changed, of course, it is likely that answers given will change too, ${ }^{128}$ and pressure to provide a 'clear cut' answer - from various officials - increased on the Attorney General in early 2003. ${ }^{129}$

There are numerous other findings in section 5 of the Report that indicate - despite the contention of some officials ${ }^{130}$ - that political pressure was placed on the UK's legal advisers. Mr Straw, for example, directly and expressly challenged some of the initial advice of the Attorney General in relation to the assessment of 'material breach' of resolution $1441,{ }^{131}$ as well as rejecting - in a significant, and 'unusual', ${ }^{132}$ exchange with Sir Michael Wood - the considered legal position of the FCO's principal legal adviser. ${ }^{133}$ The Foreign Secretary also noted in February 2003 that, however desirable a second resolution may have been, a

\footnotetext{
124 ibid [685].

125 ibid [555].

126 ibid [459].

${ }^{127}$ See, e.g., ibid [85, 563 and 708]

${ }^{128}$ See ibid [117 and 127].

${ }^{129}$ ibid [686]. See also ibid [85, 701, 857-63, 872, 878 and 950].

${ }^{130}$ See, e.g., ibid [736].

131 ibid [412].

132 ibid [359].

133 ibid [341-95].
} 
combination of the Government's policy goals and the diplomatic reality at the UN meant that the UK was 'likely to have to go for something less', ${ }^{134}$ a statement of intent that one might reasonably assume heaped pressure on the advisers who were presenting an opinion to the effect that 'less' would be legally insufficient.

Similarly, the Prime Minister's private determination to push ahead with the intervention in the early months of $2003^{135}$ and the specific finding of the Inquiry that he expressed concern to Lord Goldsmith that the formal legal opinion that a 'reasonable case' could be made 'did not offer a clear indication that military action would be lawful' ${ }^{136}$ also almost certainly contributed to the pressure on the Attorney General and other legal advisers to present a strong case for the use of force. This is especially apparent when it is considered that this was combined with the increasing opposition to the war, including from within government. ${ }^{137}$

Perhaps most notably, Lord Goldsmith confirmed that the key steps of the revival argument, in the first instance, 'had been put to [him]' by Sir Jeremy Greenstock. ${ }^{138}$ This inverse flow of legal advice - from diplomat to the UK's most senior legal adviser - may be seen as representative of the strong implication in section 5 of the Chilcot Report that diplomatic and policy concerns detrimentally influenced the independence of legal advice and, as a result, reduced the substantive quality of the advice given.

None of this is to say that the Attorney General was not circumspect about the importance of his advice remaining independent from political influence. Lord Goldsmith explained his general view about the qualities of legal advice to government, noting, in particular, that lawyers should offer advice that they 'honestly consider to be correct' and give

\footnotetext{
134 ibid [408]

135 ibid [449].

${ }^{136}$ See, e.g., ibid [292].

${ }^{137}$ See, e.g., ibid [602].

138 ibid [294] (emphasis added).
} 
'advice they believe in' and not what 'they think others want to hear.' ${ }^{139}$ He further explained some of the negative consequences of legal advisers not acting in this independent manner, pointing out that this 'would undermine their function'. ${ }^{140}$ Nonetheless, it would not seem that this goal of maintaining lawyerly independence was adequately realised.

Overall, therefore, perhaps the most crucial lesson of all to learn from the Chilcot Report - in relation to questions of international law - is the need to protect the independence of legal advice to governments. Simply put, our view is that a decision by government to reject advice reached independently is a better alternative to allowing legal advice to be pressured so as to suit governmental policy.

Legal advisers do not exist in a political vacuum, and they are, in some respects, slaves to two masters: they are required to be conscientious about their specific client - the government of the day - but are also interested in broader questions of fidelity to the rule of law. Different lawyers will weigh the balance between these two concerns differently. Elizabeth Wilmshurst, of course, famously resigned her post. ${ }^{141}$ Sir Michael Wood, on the other hand - once it was clear that his legal opinion was not going to be accepted - retained fidelity to 'the client', and shifted from 'advisory decision-making mode' to 'advocacy mode'. ${ }^{142}$

One cannot reach a conclusion as to a 'better' way for these dual responsibilities - to the client and to the law - to be reconciled by individuals. What we would argue is that the role of the legal officer, as both adviser and advocate, requires not only that he or she has the clearest possible picture of the legal rules, but also involves, at least at times, the formulation

\footnotetext{
139 ibid [357].

140 ibid [357 and 377].

141 See 'Wilmshurst Resignation Letter' $B B C \quad$ News $\quad(24 \quad$ March 2005) http://news.bbc.co.uk/1/hi/uk_politics/4377605.stm.

${ }^{142}$ Chilcot Report (n 7) volume 5, section 5 [797].
} 
of a genuine opinion on how those rules apply and ought to be interpreted. ${ }^{143}$ To meaningfully fulfil this role, legal advisers must be provided with sufficient independence, and the genuine opportunity to provide informed expert advice.

\section{Conclusion}

In this article, we have offered some initial thoughts as to the treatment of international law and international legal advice in the recently published Chilcot Report. The Inquiry did not make explicit legal determinations - we argue probably desirably - and, despite the temptation to do so, it is dangerous to infer any legal conclusions from its Report. There are certainly some unflinching findings in the Report, such as the already now infamous revelation that the Prime Minister wrote to President Bush in July 2002 stating 'I will be with you whatever', ${ }^{144}$ and the Inquiry's conclusion that 'the UK's actions undermined the authority of the Security Council. ${ }^{145}$ Chilcot was not the whitewash that some feared. ${ }^{146}$ Nonetheless, even the Report's most hard-hitting conclusions do not, in themselves, have direct legal implications.

What the Report did do was engage with international law to a notable extent. Moreover, its treatment of international law was, for the most part, both accurate and accessible. This is undoubtedly a positive consequence of the Inquiry's work, which has implications for the wider social appreciation of international legal standards and for the role of international law in future commissions of inquiry.

Far more extensive still was the Report's consideration of the provision and treatment of legal advice. We have argued that Chilcot demonstrates a worrying trend amongst

\footnotetext{
143 See Jean d'Aspremont, 'The Multidimensional Process of Interpretation: Content-Determination and LawAscertainment Distinguished' in Andrea Bianchi, Daniel Peat and Matthew Windsor (eds), Interpretation in International Law (Oxford University Press 2015).

${ }^{144}$ Chilcot Report (n 7) executive summary [94].

145 ibid [439].

${ }^{146}$ See, e.g., Andy Beckett, 'Revelation or Whitewash - What Can We Expect from the Chilcot Inquiry?' The Guardian (4 July 2016) www.theguardian.com/uk-news/2016/jul/04/chilcot-inquiry-iraq-war-whitewash.
} 
government officials to marginalise, delay and obfuscate legal advice, ${ }^{147}$ at least with regard to the events considered by the Inquiry. One must be careful not to overstate this trend, but it was undoubtedly a notable aspect of decision-making in relation to the Iraq War. As the Inquiry's chairperson made clear in his statement accompanying the publication of the Report, 'the circumstances in which it was decided that there was a legal basis for UK military action were far from satisfactory. ${ }^{148}$ In this article, we particularly stress that crucial lessons to learn from Chilcot are the need for officials to respect legal advice (including fully justifying deviation from it), and the importance of protecting the independence of the legal adviser.

${ }^{147}$ See, e.g., Ministerial Code (Cabinet Office 2015) (making no reference at all to international law). ${ }^{148}$ Statement by Sir John Chilcot (6 July 2016) (n 15) 4. 